\title{
A novel method for quantitating delayed enhancement of the left atrium
}

\author{
Christian B Moyer ${ }^{1}$, Loren P Budge $2^{*}$, Patrick T Norton², Christopher M Kramer ${ }^{2}$, John D Ferguson², \\ Jeffrey W Holmes ${ }^{1}$
}

From 2011 SCMR/Euro CMR Joint Scientific Sessions

Nice, France. 3-6 February 2011

\section{Introduction}

Delayed contrast enhancement of the left atrium (DE-LA) in patients with atrial fibrillation (AF) has been reported to correlate well with outcomes after catheter ablation of AF. Currently utilized methods for DE-LA assessment require intensive post-processing and significant user-defined thresholding to obtain meaningful results.

\section{Purpose}

We aimed to develop an accurate, reproducible method of DE-LA quantitation requiring less intensive post- processing and decreased user input, and to test this method in a typical AF population undergoing CMR.

\section{Methods}

16 Patients with AF (7 with prior ablation, 9 with no history of ablation; 11 with paroxysmal AF, 5 with persistent AF) underwent CMR on a 1.5-T Siemens Avanto scanner. DE-LA images were acquired 15 min after contrast injection using a 3D inversion recovery, respiration-navigated, fat suppressed, ECG-gated, gradient echo pulse sequence, with acquisition parameters as follows: voxel size $1.2 \times 1.2 \times 2.5 \mathrm{~mm}$, field of view: $30 \times 30 \mathrm{~cm}$,
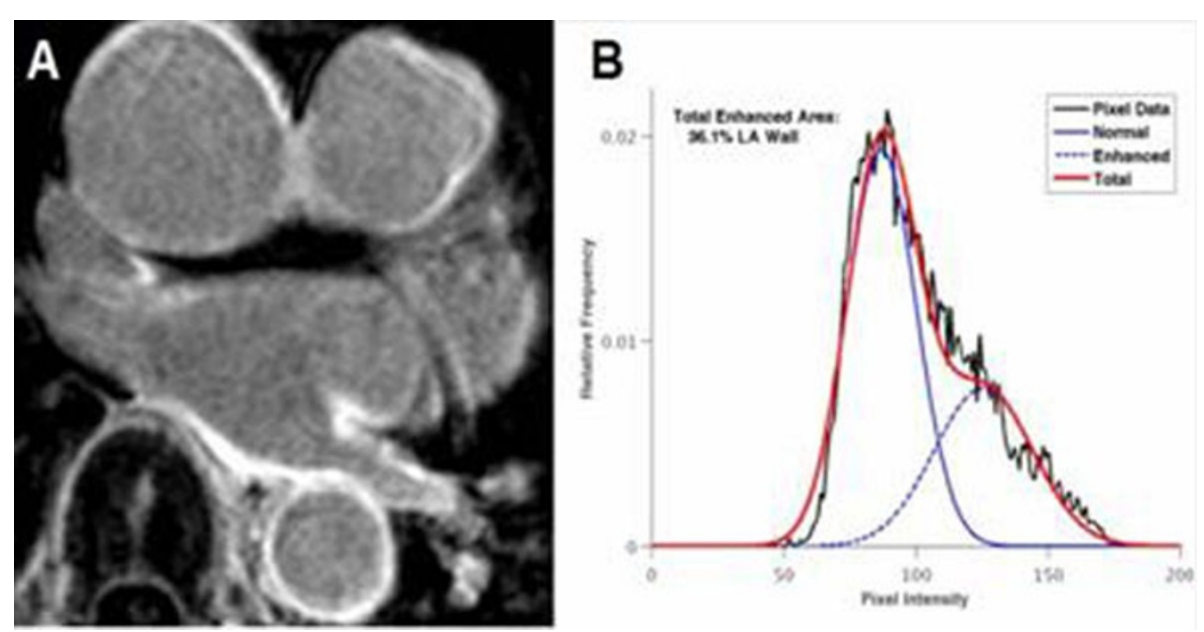

Figure 1 A representative DE-LA sample from a patient with prior ablation. A Axial DE-LA image showing enhancement of the left inferior pulmonary vein and posterior left atrial wall. B A pixel histogram of this patient, demonstrating two distinct pixel populations within the left atrial wall.

${ }^{2}$ University of Virginia Health System, Charlottesville, VA, USA

Full list of author information is available at the end of the article

(c) 2011 Moyer et al; licensee BioMed Central Ltd. This is an open access article distributed under the terms of the Creative Commons 
TR/TE: $4.3 / 2.4 \mathrm{~ms}$, flip angle: $15^{\circ}$, bandwidth: 360 $\mathrm{Hz} /$ pixel, inversion time (TI) is based on a TI scout (range: 250-350 ms), with an average scan time of 5-9 minutes. To quantify DE-LA, we manually segmented the epicardial border of the left atrium, then extrapolated radially inward at a constant thickness (3 pixels) to define the endocardial border. Pixels within the contoured regions were tabulated into a pixel intensity histogram comprising the entire LA wall volume. We assumed the total distribution was composed of two underlying parts: normal and enhanced tissue. To separate these overlapping distributions, we fitted a mixture model containing two continuous Gaussian distributions, weighted by their respective areas. Using MATLAB, an intensity threshold was defined automatically at the intersection of the two distributions. The volume of enhancement isolated by the automatic threshold was then calculated and normalized to the total LA wall volume. Results are reported as a percentage of LA wall volume, and significant differences were determined using unpaired $t$-tests.

\section{Results}

DE-LA was higher in patients with a previous AF ablation compared to patients with no prior left atrial ablation $(19.8 \%$ vs. $9.5 \%, \mathrm{p}<0.04)$. No difference in DE-LA was seen between paroxysmal and persistent AF ( $14.7 \%$ vs. $12.6 \%$, respectively. $\mathrm{p}=\mathrm{NS}$ ). Figure 1 .

\section{Conclusions}

We have developed a novel method for quantitating DE-LA, which requires decreased user input compared to previously published methods. Using this method, we have shown a significant increase in DE-LA in patients who have had past ablation of AF compared to those without prior ablation.

\footnotetext{
Author details

${ }^{1}$ University of Virginia, Charlottesville, VA, USA. ${ }^{2}$ University of Virginia Health System, Charlottesville, VA, USA.
}

Published: 2 February 2011
doi:10.1186/1532-429X-13-S1-P248

Cite this article as: Moyer et al:: A novel method for quantitating delayed enhancement of the left atrium. Journal of Cardiovascular Magnetic Resonance 2011 13(Suppl 1):P248.

\section{Submit your next manuscript to BioMed Central} and take full advantage of:

- Convenient online submission

- Thorough peer review

- No space constraints or color figure charges

- Immediate publication on acceptance

- Inclusion in PubMed, CAS, Scopus and Google Scholar

- Research which is freely available for redistribution

Submit your manuscript at www.biomedcentral.com/submit 